Document downloaded from:

http://hdl.handle.net/10251/51378

This paper must be cited as:

Tora Grau, M.; Soler Cabezas, JL.; Vincent Vela, MC.; Mendoza Roca, JA.; Martínez Francisco, FJ. (2014). Comparison of different model solutions to simulate membrane fouling in the ultrafiltration of a secondary effluent from a municipal wastewater treatment plant. Desalination and Water Treatment. 1-7. doi:10.1080/19443994.2014.939865.

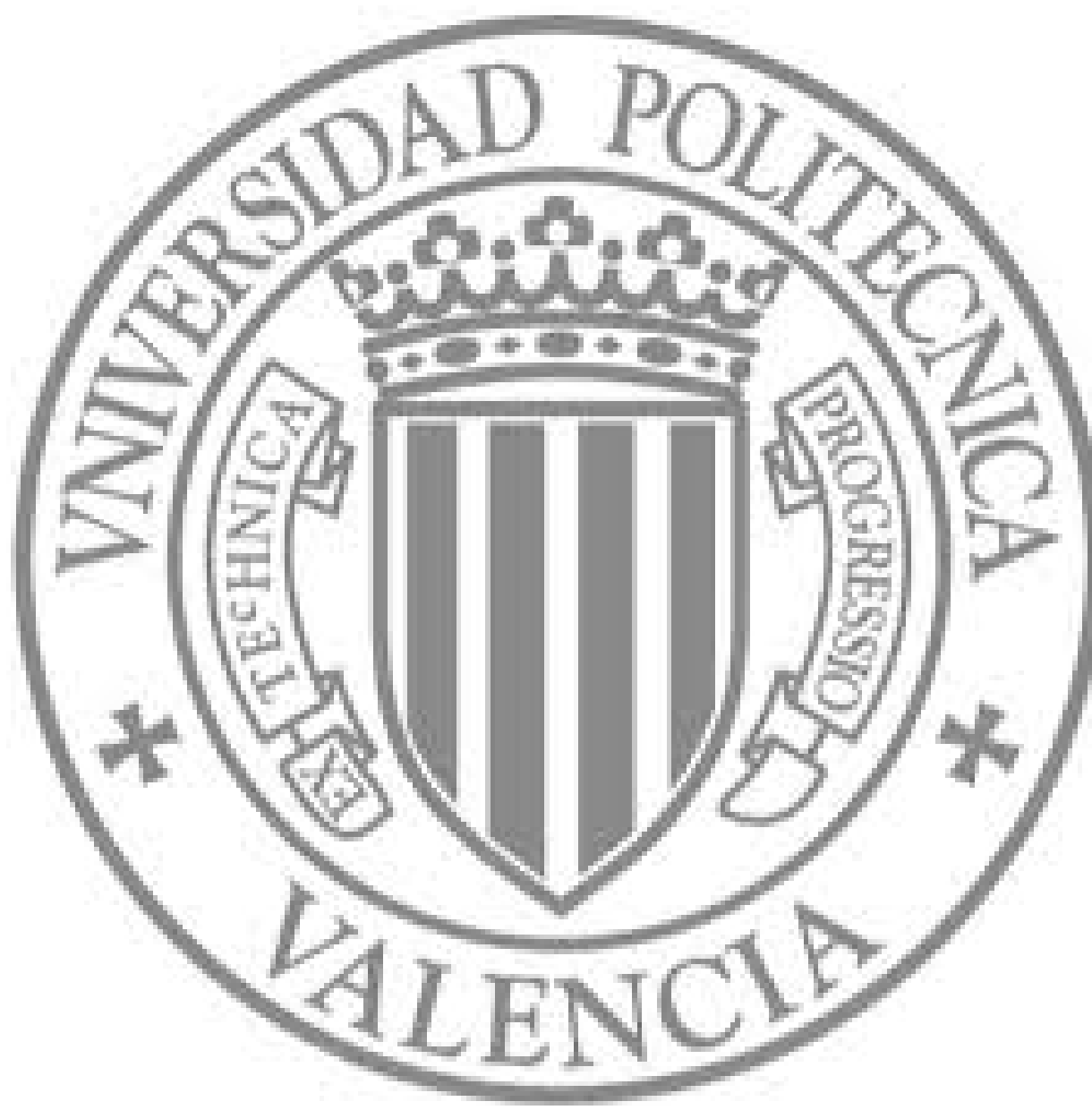

The final publication is available at

http://dx.doi.org/10.1080/19443994.2014.939865

Copyright

Taylor \&amp;amp; Francis: STM, Behavioural Science and Public Health Titles 
This is an Author's Original Manuscript of an article published by Taylor \& Francis Group in Desalination and Water Treatment on 21/07/2014, available online at: http://www.tandfonline.com/10.1080/19443994.2014.939865

\title{
COMPARISON OF DIFFERENT MODEL SOLUTIONS TO SIMULATE MEMBRANE FOULING IN THE ULTRAFILTRATION OF A SECONDARY EFFLUENT FROM A MUNICIPAL WASTEWATER TREATMENT PLANT.
}

Authors: M. Torà-Grau, J.L. Soler-Cabezas, M.C. Vincent-Vela*, J.A. Mendoza-Roca, F.J. MartínezFrancisco.

Universitat Politècnica de València. Instituto de Seguridad Industrial, Radiofísica y Medio Ambiental. Camino de Vera s/n 46022 Valencia

* Tlf: +34 3877000 ext. 79387 Fax: +34963877639 email: mavinve@iqn.upv.es

Topic: ultrafiltration

Keywords: ultrafiltration, simulated wastewater, municipal treatment plant, fouling.

\begin{abstract}
The quality of the secondary treatment effluent from a Municipal Wastewater Treatment Plant is not good enough for some applications such as agriculture. Membrane ultrafiltration has been proven to be a reliable tertiary treatment to achieve the needed water quality. The productivity of the ultrafiltration processes depends on the membrane fouling. The aim of this work is to prepare a model wastewater that could mimic the fouling trend of a secondary treatment effluent wastewater from a Municipal Wastewater Treatment Plant. Several model wastewaters consisting of different proteins and carbohydrates were used in the ultrafiltration experiments. Ultrafiltration was also performed with a secondary treatment effluent. The membrane used in the ultrafiltration tests was a UFCM5 from Norit X-flow ${ }^{\circledR}$ hydrophilic polyethersulfone/polyvinylpyrrolidone blend hollow fiber ultrafiltration membrane of $200 \mathrm{KDa}$ molecular weight cut-off with a fiber diameter of $1.5 \mathrm{~mm}$. Membrane configuration was insideout. Ultrafiltration tests with model wastewater and secondary treatment effluent wastewater were compared. The results showed that the best model wastewater which represents the fouling trend of secondary treatment effluent wastewater is the model wastewater whose composition is $15 \mathrm{mg} / \mathrm{l}$ of bovine serum albumin and $5.5 \mathrm{mg} / \mathrm{l}$ of dextran.
\end{abstract}




\section{Introduction}

The conventional treatment of municipal wastewater consists of a pretreatment, followed by a primary treatment (physico-chemical), a secondary treatment (activated sludge is the most used process) and, depending on each case, a tertiary treatment.

The need for a tertiary treatment is due to the fact that the water quality resulting from a secondary treatment could not be good enough for some applications, for example in agriculture where disinfection (pathogens removal) is very important.

A commonly used tertiary treatment is ultrafiltration (UF). UF can be applied to the reclamation of municipal wastewater [1]. In fact, UF can meet high quality standards [2] and can achieve disinfection (pathogens removal) $[3,4,5,6]$. Compared to conventional treatments, UF has some advantages: high permeate quality, no by-product generation, high efficiency, easy to operate, economically feasible, reduced membrane costs and energy consumption, low pressure, small footprint ...[3,7,8,9,10].

Currently, studies show that the best UF membranes for secondary treatment effluent (STE) from a Municipal Wastewater Treatment Plant (MWWTP) are hollow-fiber membranes $[2,11]$. Hollow fiber membranes are widely used for large-scale water treatment due to the relatively large packing density [12]. In spite of this configuration, the major problem of membrane filtration is still fouling [13]. Fouling is responsible for permeate flux decline [14] (this causes productivity loss), higher operating costs [15] (due to higher energy cost [15] and the need of frequent membrane cleaning), and higher maintenance costs [16] (due to lower membrane lifetime [13] and frequent membrane replacement needs). In addition, fouling is responsible for lower plant availability due to membrane replacement and cleaning operations [16].

Minimizing flux decline is important so that the process could be economically feasible [17]. Membrane fouling has been studied extensively by the scientific community and it is still been studied $[18,19]$ because fouling mechanisms are not completely understood.

Due to the fact that the characteristics of a STE from a MWTP are very variable, modelling the ultrafiltration process may help to select the best operational conditions to minimize fouling, avoiding time consuming experiments.

The use of a simplified model wastewater consisting of only few compounds may help to understand the fouling mechanisms during UF. This is an important and necessary step in order to model the fouling process.

Proteins and carbohydrates are commonly used in model wastewaters to simulate STE since these are the main components of the extracellular polymeric substances (EPS), which are known to be the primarily responsible for membrane fouling in biological effluents $[8,18,19]$. Thus, other authors have studied them as model foulants previously obtaining good results. For example, xanthan was used by Nataraj et al. [20], dextran and Bovine Serum Albumin (BSA) were studied by Zator et al. [21] and Xiaou et al. [22] and Whey Protein Concentrate (WPC) was used by Nigam [23], Mourouzidis [24] and Caric et al. [25]. 
The aim of this research was to obtain a synthetic model wastewater composition that could mimic the fouling trend of the hollow-fiber membrane used in the ultrafiltration of a secondary clarifier effluent from a MWTP. In order to achieve that aim, different combinations of model proteins and carbohydrates at different concentrations were prepared and their UF performance was compared with real wastewater UF performance.

Protein and carbohydrates concentration and also chemical oxygen demand (COD) were determined for real and model wastewaters to select the most appropriate model wastewater.

The model proteins used were WPC 45\% and BSA and the carbohydrates used were dextran (250 kDa of molecular weight (MW)) and xanthan.

\section{Materials and Methods}

\subsection{STE and model wastewater characterization}

STE from a MWWTP and model wastewater were characterized measuring the following parameters at laboratory: proteins and carbohydrates concentration and chemical oxygen demand (COD).

The COD was measured using the kits and a thermoreactor model "TR300" both from Merck. The proteins concentration was determined by a MicroBCA assay (Bicinchoninic acid protein assay micro) from Applichem. Carbohydrates concentration was determined by the anthrone (9, 10 dihydro-9-ketoanthracene) method (reagent from Panreac).

\subsection{Model wastewater/preparation}

Model solutions were prepared using tap water. The proteins used were: BSA from SigmaAldrich, and WPC $(45 \% \mathrm{w} / \mathrm{w})$. The carbohydrates used were dextran 250000 Da from VWR International Ltd and xanthan gum (from xanthomonas campestris, Sigma-Aldrich).

Different combinations and concentrations of the aforementioned proteins and carbohydrates were tested to select a model wastewater that could mimic the STE.

\subsection{Particle size distribution (PSD)}

In order to determine the particle size distribution a Zetasizer nano-ZS 90 from Malvern was used. This equipment measures the particle size by laser diffraction. Results have been expressed in intensity (the magnitude measured by the apparatus). 


\subsection{Pilot plant}

A Norit $X$-flow $T / R X-300$ commercial pilot plant was used for the tests (Figure 1 ). This plant allows the transmembrane pressure (TMP) and crossflow velocity (CFV) to be fixed independently. A temperature regulator kept the temperature constant during the experiments. Data were logged in a programmable logic controller (PLC). The feed tank was stirred during the test.

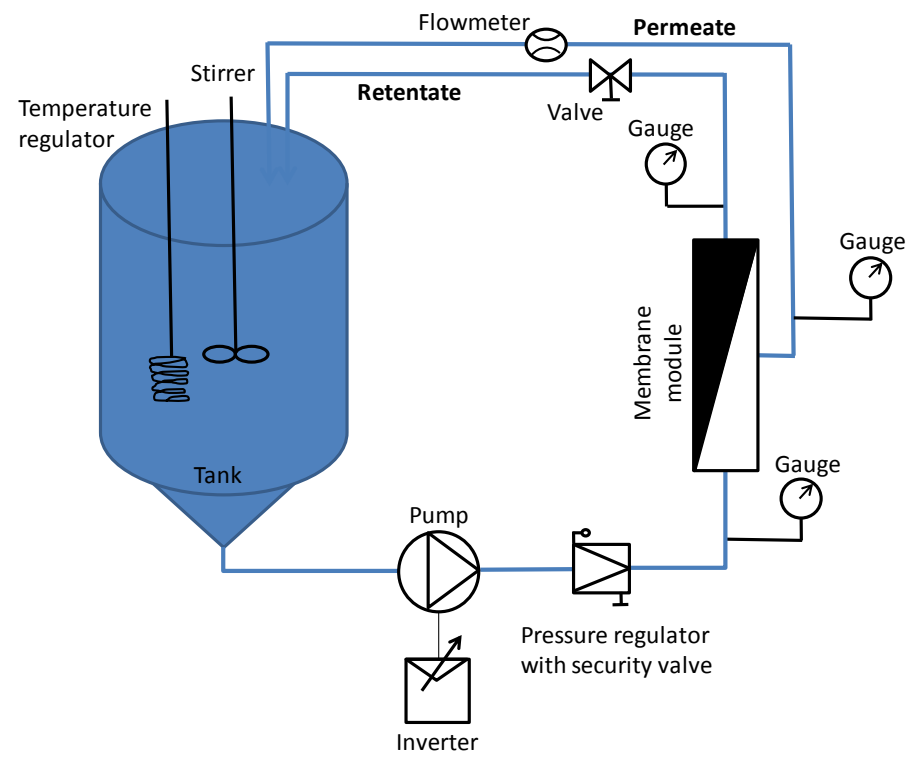

Figure 1. UF Pilot plant scheme.

\subsection{UF Membrane}

A hollow-fiber membrane was used for ultrafiltration tests. The membrane used was a UFCM5 from Norit X-flow with a fiber diameter of $1.5 \mathrm{~mm}$, a molecular weight cut-off (MWCO) of $200 \mathrm{kDa}$ and the active area was $0.04 \mathrm{~m}^{2}$. The membrane material was polyethersulfone/polyvinylpyrrolidone (PES/PVP). The membrane had hydrophilic properties and its configuration was inside-out.

\subsection{Fouling UF tests}

During the UF tests, the retentate and the permeate were both returned to the feed tank and permeate flux was monitored. The tests performed with simulated wastewater and STE were carried out at the same TMP, CFV and temperature (TMP=70 KPa, CFV=1m/s, $T=21$ 으). These experimental conditions were selected on the basis of previous studies $[2,27]$ that showed that the best performance of these membranes is achieved at low pressure due to 
reduced membrane fouling. For example Hao et al. [26] used a feed solution of humic acid and ethylenediaminetetraacetic acid (EDTA) at 0.5 bar. Tasselli et.al. [27] worked at a cross flow velocity in the range of $0.59-2.96 \mathrm{~m} / \mathrm{s}$ and with a feed solution of kiwifruit juice. Tasselli found that the optimal velocity value was in that range. In addition, other authors as Marcos et al. [28] and Chung et al. [29], worked at a CFV of $1 \mathrm{~m} / \mathrm{s}$ with soy proteins and dextrans, respectively.

\subsection{Membrane cleaning}

After the UF fouling experiments, membrane cleaning was performed to restore initial membrane permeability. The cleaning protocol was performed at the lowest TMP and highest CFV so that the pilot plant could achieved.

The cleaning protocol was:

1. First rinsing: 30 minutes at $25 \circ \mathrm{C}$ with deionized water.

2. Chemical cleaning: the cleaning solution consisted of $154 \mathrm{ppm}$ of $\mathrm{NaClO}$ and 0.5 $\mathrm{mol} / \mathrm{l}$ of $\mathrm{NaOH}$ (Panreac, Spain) in deionized water. The chemical cleaning was performed at $40^{\circ} \mathrm{C}$ of temperature.

3. Second rinsing: the same conditions as the first rinsing.

\section{Results and discussion}

The STE wastewater was characterized in terms of proteins, carbohydrates and COD. The results are shown in Table 1 as well as the standard deviation of these parameters. The standard deviation was calculated from several samples. The values of the concentration of proteins, carbohydrates and COD were used to prepare the model wastewater.

Table 1. STE composition.

\begin{tabular}{ccc}
\hline Parameter & STE & Standard deviation \\
\hline Proteins (mgBSA/l) & 16.48 & 4.28 \\
Carbohydrates (mg glucose/l) & 7.32 & 1.41 \\
COD (mg/l) & 38.9 & 4.84 \\
\hline
\end{tabular}

As it can be observed, COD values are rather low. This is explained by the excellent performance of the activated sludge process in the MWWTP where the samples were taken.

The model wastewater composition (Table 2) was selected so that the measured concentration of proteins and carbohydrates was similar to the STE. 
Table 2. Model wastewater composition.

\begin{tabular}{|c|c|c|c|c|}
\hline $\begin{array}{c}\text { Model } \\
\text { wastewater } \\
\text { No. } \\
\end{array}$ & Composition & $\begin{array}{c}\text { Proteins } \\
(\mathrm{mg} \text { BSA } / \mathrm{L})\end{array}$ & $\begin{array}{l}\text { Carbohydrates } \\
\text { (mg glucose/L) }\end{array}$ & $\begin{array}{c}\text { COD } \\
(\mathrm{mg} / \mathrm{L})\end{array}$ \\
\hline 1 & $10 \mathrm{mg} / \mathrm{L}$ WPC $45 \%$ & 7.0 & 4.1 & 8 \\
\hline 2 & $13 \mathrm{mg} / \mathrm{L}$ WPC $45 \%$ & 11.5 & 6.0 & 9 \\
\hline 3 & $17.71 \mathrm{mg} / \mathrm{L}$ WPC $45 \%$ & 18.8 & 5.9 & 19 \\
\hline 4 & $15.75 \mathrm{mg} / \mathrm{L}$ WPC $45 \%+5.5 \mathrm{mg} / \mathrm{L}$ dextran & 13.0 & 14.2 & 28 \\
\hline 5 & $15.75 \mathrm{mg} / \mathrm{l} \mathrm{WPC} 45 \%+7.315 \mathrm{mg} / \mathrm{l}$ dextran & 10.8 & 15.7 & 21 \\
\hline 6 & $15.75 \mathrm{mg} / \mathrm{L}$ WPC $45 \%+8.57 \mathrm{mg} / \mathrm{L}$ xanthan & 15.3 & 8.5 & 38 \\
\hline 7 & $15 \mathrm{mg} / \mathrm{lBSA}+5.5 \mathrm{mg} / \mathrm{l}$ dextran 250.000 & 17.3 & 7.6 & 27 \\
\hline
\end{tabular}

It can be observed that the values of the "proteins" and "carbohydrates" columns correspond with measured data, meanwhile the column "composition" corresponds with the weight measurement carried out to prepare the model solutions.

Katsoufidou et al. [8] performed fouling tests using alginate as model foulant. However, their results showed that alginate was not a good model foulant due to the formation of a hydrogel layer. Thus, alginate was not considered in this study.

The mixture BSA/dextran had already been investigated by Zator et al. [21] and Xiao et al. [22]. WPC was also studied by Nigam [23], Mourouzidis [24] and Caric et al. [25]. Xanthan was studied by Nataraj et al. [20]. Zator et al. [21] found that particle size has an important role in membrane fouling and that smaller particles produced less fouling (more permeate flux) than the bigger particles. They also concluded that the fouling mechanisms of smaller particles were internal and external pore blocking. As well, they considered the internal fouling as the predominant mechanism. In addition, their results showed that the adsorption of proteins caused a progressive pore diameter reduction. Nguyen et al. [30] worked with BSA and WPC. They proposed a model for proteins in which pore blockage and compressive cake mechanisms occurred simultaneously. Regarding to the fouling mechanisms of xanthan, Nataraj et al. [20] concluded that the predominant mechanism depends on the concentration. For low concentrations $(<20 \mathrm{mg} / \mathrm{l})$, the predominant fouling mechanism is cake formation and for high concentrations (> $20 \mathrm{mg} / \mathrm{l}$ ) the predominant fouling mechanism is a combination of cake formation and pore constriction.

It must be noted that the measured protein and carbohydrate concentrations for the model wastewater 7 (Table 2) were more similar to the measured values for the STE (Table 1) than in the case of the rest of the model wastewaters prepared. As far as COD is concerned, the solution that better approximates to the STE is the model wastewater 6 . In addition, it can be seen that the model wastewaters whose composition consists of only WPC $45 \%$ contain both protein and carbohydrates in a concentration similar to the STE.

The fact that the model composition could be the most similar to the STE does not imply coincidence in the fouling trend. Because of this, UF tests were performed to compare the fouling trends of model wastewater and the STE. The use of proteins and carbohydrates of 
different MW to prepare the model wastewater is explained by the wide range of the MW of the soluble microbial products found in the literature [31].

Figure 2 shows the results of these UF tests. The permeate flux represented in Figure 2 corresponds to the normalized permeate flux $\left(\mathrm{J}_{\mathrm{N}}\right)$ according to Eq.1. Normalization was performed due to the fact that the initial membrane permeability was not exactly the same for all UF tests as the cleaning efficiency was not always exactly $100 \%$.

$$
I_{N}=J \cdot \frac{R_{0}}{R_{m}}
$$

Eq.1.

Where $J$ is the permeate flux obtained during the test, $J_{N}$ is the normalized permeate flux, $R_{0}$ is the resistance of the membrane before its first use and $R_{m}$ is the membrane resistance before each test.

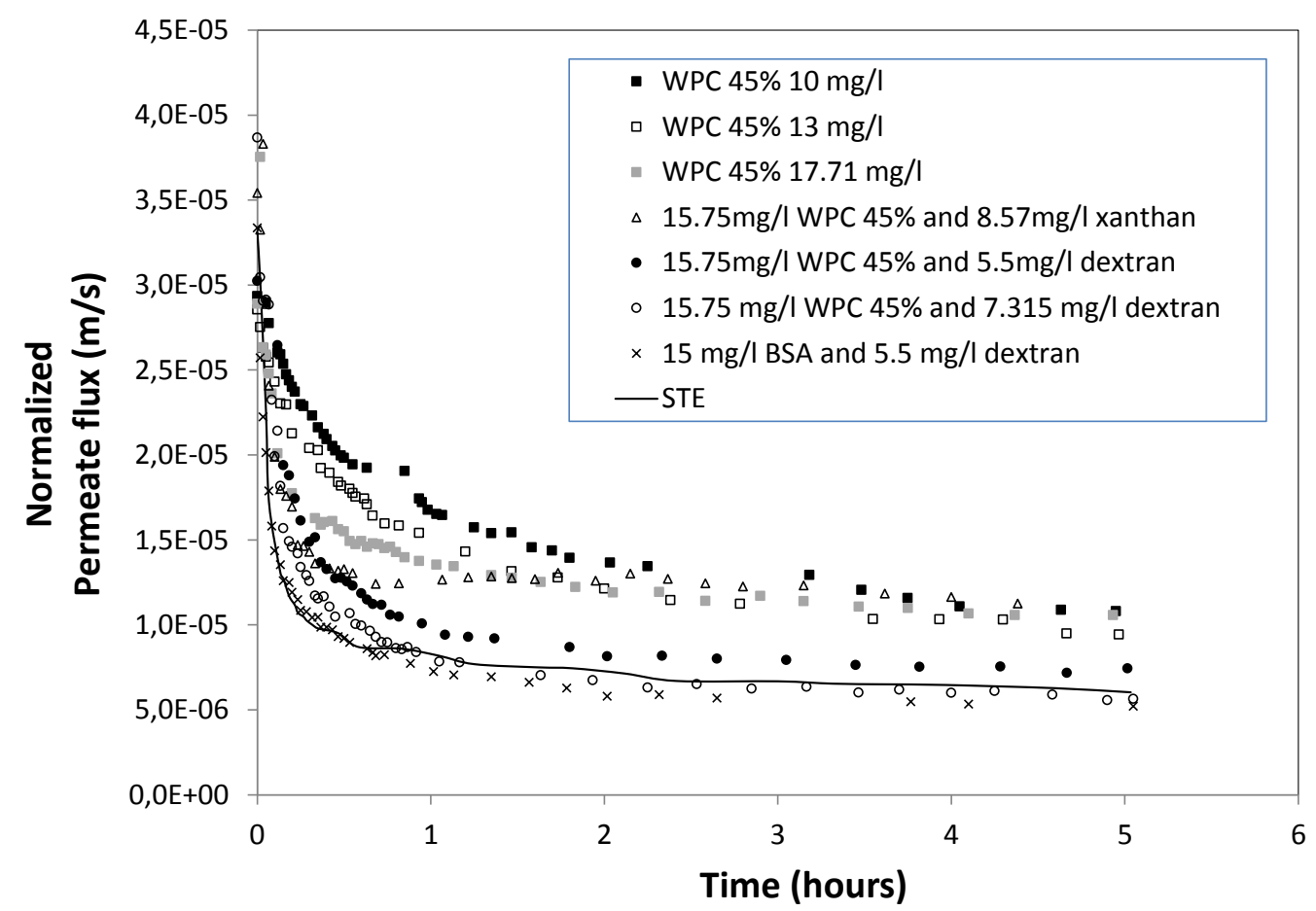

Figure 2. Flux decline vs time for STE and model wastewater for a transmembrane pressure of 0.7 bar and a crossflow velocity of $1 \mathrm{~m} / \mathrm{s}$.

Although model solutions $(1,2,3)$ consisting only of WPC contained both proteins and carbohydrates, Figure 2 showed that an increase of WPC concentration mainly had an effect on initial permeate flux decline. However, steady-state permeate flux remained almost constant when increasing WPC concentration. This fact is justified due to the foulant molecular weight. The WPC molecular weight $(25000 \mathrm{Da})$ is lower than the MWCO of the membrane (200000 Da) so that WPC permeates through the membrane and it contributes mainly to pore blocking fouling mechanisms. These mechanisms are known to occur during the very early stages of UF. Therefore, the use of WPC alone and not in combination with dextran did not 
reproduce the fouling trend of the STE. The steady-state permeate flux for the solutions tested consisting of WPC $45 \%$ is higher than the permeate flux of the STE.

WPC in combination with dextran and xanthan was also tested. The results showed that the use of xanthan is not appropriate since steady state permeate flux remains practically equal to that obtained with WPC alone. However, the combination of dextran and WPC approximately achieves to represent the STE fouling trend.

Xantham gum is a microbial polysachharide. According to the literature, its $\mathrm{MW}$ is around $3 \cdot 10^{6} \mathrm{Da}$ [32]. If tests 5 and 6 are compared, it can be concluded that the effect of dextran (MW $250000 \mathrm{Da}$ ) on the loss of membrane permeate flux productivity is considerably higher than the effect of xanthan. However, the initial flux decline is very similar in both tests, what can be surprising if the difference of molecular weight of both compounds is considered. Then, PSD of a xantham solution was determined (Figure 3). Besides the peak at $110 \mathrm{~nm}$, which indicates that most of the particles have a considerable higher size than the membrane pores $(21 \mathrm{~nm})$, there are two additional peaks at 3 and $11 \mathrm{~nm}$, approximately. This can be due to partial cleavage of the polymer molecules. This fact can explain the additional flux loss at the initial part of the test in comparison with the tests performed only with WPC.

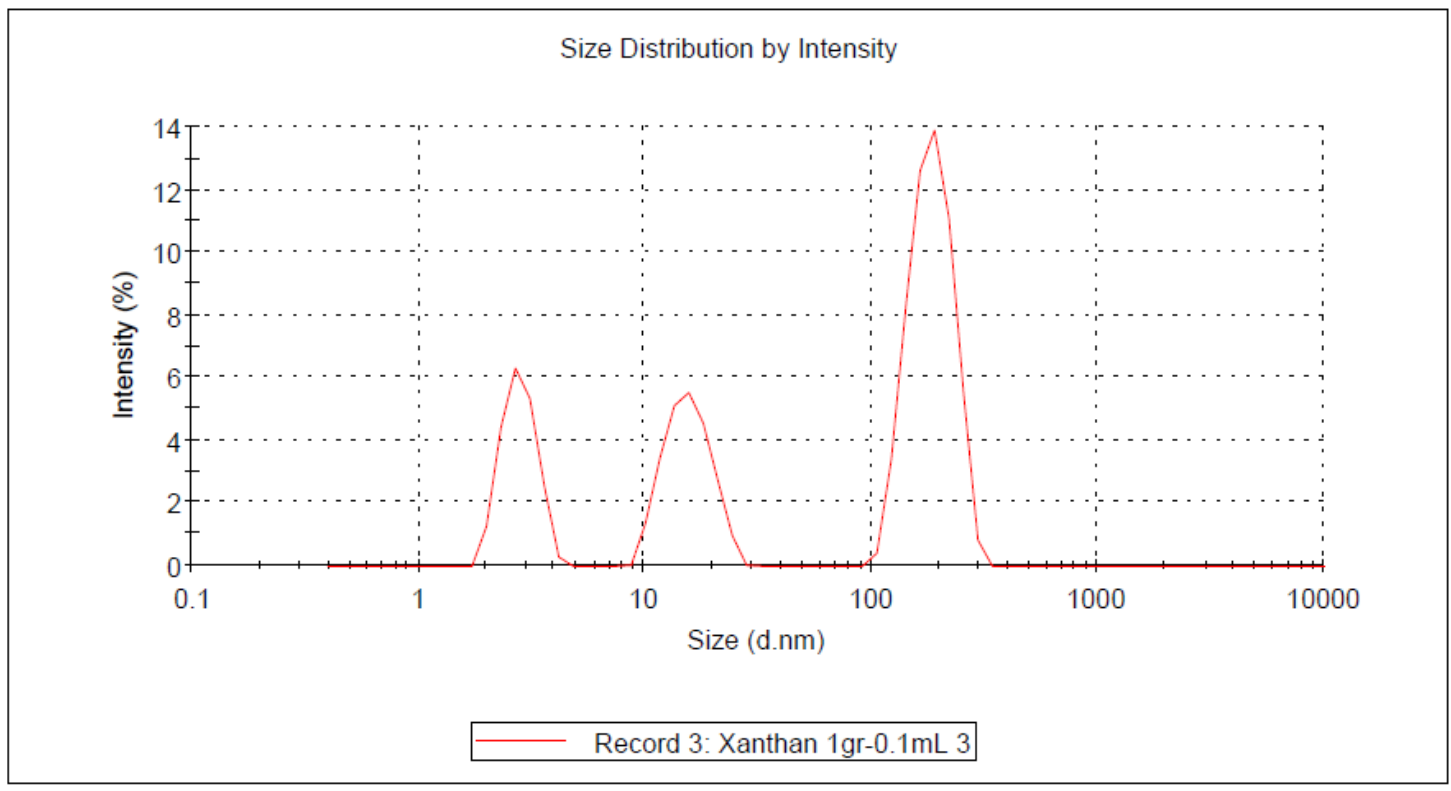

Figure 3. Particle size distribution of the Xanthan solution.

The best results were obtained for the combination of BSA and dextran. Although BSA MW (66430 Da) was lower than the membrane cut-off (200 kDa), BSA contributes to the decrease of the steady state flux (Figure 2). This indicates that BSA is deposited on the membrane surface what is corroborated by the high rejection measured (76\%). This is explained by the fouling mechanism. Kelly and Zydney [33] reported that fouling mechanisms were two: convection deposition of BSA aggregates and chemical attachment to the previously deposited proteins. However, modeling BSA fouling is complex since BSA molecules form aggregates [34], what lead to high UF membrane retention. 
Dextran addition has an effect on both initial permeate flux decline and steady state permeate flux. This can be observed in the two tests performed with the same WPC concentration and different dextran concentrations. Its MW is very similar to the membrane cut-off and the calculated retention from the carbohydrates measurements in feed and permeate streams was around $50 \%$. This confirms its eventual contribution both to pore blocking and to long term fouling.

\section{Conclusions}

In this work different model wastewaters were prepared in order to obtain a model wastewater to simulate the STE from a MWWTP. Simulation of STE is of great importance for studying the fouling mechanisms in UF membranes applied to wastewater reclamation.

When the concentration of proteins and carbohydrates of the model wastewater increases, the fouling produced is higher. Two effects were observed depending depending on the foulants used: a rapid initial permeate flux decline or a steady state with a lower permeate flux. For the foulants tested, proteins exerted more influence on initial flux decline whereas carbohydrates did on the steady-state flux.

The best model wastewater had a composition of $15 \mathrm{mg} / \mathrm{l}$ of BSA and $5.5 \mathrm{mg} / \mathrm{l}$ of dextran. This solution best mimics the initial flux decline and the difference between its steady state flux and the steady state flux of STE was negligible. On the other hand, the composition of proteins and carbohydrates of this model wastewater was very similar to the composition of the STE.

As explained before, fouling depends on the size of the particle in relation to the membrane pore size. However, changes in foulants size have to be taken into account. Thus, BSA forms aggregates and it is adsorbed on the membrane surface and xanthan solutions presented molecules shorter than the original polymer that caused pore blocking.

\section{Acknowledgements}

The authors of this work wish to gratefully acknowledge the financial support from the Generalitat Valenciana through the program "Ayudas para la realización de proyectos I+D para grupos de investigación emergentes GV/2013".

\section{References}

[1] Takashi Asano, Franklin Burton, Harold Leverenz, Ryujiro Tsuchihashi, George Tchobanoglous, Water Reuse. Issues, Technologies and Applications, McGraw-Hill. (2007).

[2] S. Delgado, F. Dıaz, L. Vera, R. Dıaz, S. Elmaleh, Modelling hollow-fibre ultrafiltration of biologically treated wastewater with and without gas sparging, J. Membr. Sci., 228 (2004) 55-63. 
[3] J. Qin, M.H. Oo, H. Lee, R. Kolkman, Dead-end ultrafiltration for pretreatment of RO in reclamation of municipal wastewater effluent, J. Membr. Sci., 243 (2004) 107-113.

[4] K. Konieczny, Disinfection of surface and ground waters with polymeric ultrafiltration membranes, Desalination, 119 (1998) 251-258.

[5] S.S. Madaeni, A.G. Fane, G.S. Grohmann, Virus removal from water and wastewater using membranes, J. Membr. Sci., 102 (1995) 65-75.

[6] J.M.Arnal Arnal, M.Sancho Fernández, G.Verdú Martín, J.Lora García, J.M.Gozálvez Zafrilla, J.Ibáñez Candela, I.Febrer Peiró, I.Terrades Martínez, Design of a membrane facility for water potabilization and its application to Third World countries, Desalination, 137 (2001) 63-69.

[7] J. Arévalo, G. Garralón, F. Plaza, B. Moreno, J. Pérez, M. A. Gómez, Wastewater reuse after treatment by tertiary ultrafiltration and a membrane bioreactor (MBR): a comparative study, Desalination, 243 (2009) 32-41.

[8] K. Katsoufidou, S.G. Yiantsios, A.J. Karabelas, An experimental study of UF membrane fouling by humic acid and sodium alginate solutions: the effect of backwashing on flux recovery, Desalination, 220 (2008) 214-227.

[9] S. Muthukumaran, D.A. Nguyen, K. Baskaran, Performance evaluation of different ultrafiltration membranes for the reclamation, Desalination, 279 (2011) 383-389.

[10] R. K. Henderson, N. Subhi, A. Antony, S. J. Khan, K. R. Murphy, G. L. Leslie, V. Chen, R. M. Stuetz, P. Le-Clech, Evaluation of effluent organic matter fouling in ultrafiltration treatment using advanced organic characterisation techniques, J. Membr. Sci., 382 (2011) 50- 59.

[11] L. Fan, T. Nguyen, F. A. Roddick, J. L. Harris, Low-pressure membrane filtration of secondary effluent in water reuse: Pretreatment for fouling reduction, J. Membr. Sci., 320 (2008) 135-142.

[12] D. Xiao, W. Li, S. Chou, R. Wang, C. Y. Tang, A modeling investigation on optimizing the design of forward osmosis hollow fiber modules, J. Membr. Sci., 392-393 (2012), 76-87.

[13] Y. Kaya, H. Barlas, S. Arayici, Evaluation of fouling mechanisms in the nanofiltration of solutions with high anionic and nonionic surfactant contents using a resistance-in-series model, J. Membr. Sci., 367 (2011) 45-54.

[14] C.H. Yu, L.C. Fang, S. K. Lateef, C.H. Wu, C.F. Lin, Enzymatic treatment for controlling irreversible membrane fouling in cross-flow humic acid-fed ultrafiltration, J. Hazard. Mater., 177 (2010) 1153-1158.

[15] W. Gao, H. Liang, J. Ma, M. Han, Z. Chen, Z. Han, G. Li, Membrane fouling control in ultrafiltration technology for drinking wáter production: A review, Desalination, 272 (2011) 1-8.

[16] M. A. Saad, Early discovery of RO membrane fouling and real-time monitoring of plant performance for optimizing cost of water, Desalination, 165 (2004) 183-191.

[17] A. Jayalakshmi, S. Rajesh, D. Mohan, Fouling propensity and separation efficiency of epoxidated polyethersulfone incorporated cellulose acetate ultrafiltration membrane in the retention of proteins, Appl. Surf. Sci., 258 (2012) 9770-9781.

[18] F. Qu, H. Liang, Z. Wang, H. Wang, H. Yu, G. Li, Ultrafiltration membrane fouling by extracellular organic matters (EOM) of Microcystis aeruginosa in stationary phase: Influences of interfacial characteristics of foulants and fouling mechanisms, Water research, 46 (2012) 1490-1500.

[19] C. Wang, Q. Li, H. Tang, D. Yan, W. Zhou, J. Xing, Y. Wan, Membrane fouling mechanism in ultrafiltration of succinic acid fermentation broth, Bioresour. Technol., 116 (2012) 366-371. 
[20] S. Nataraj, R. Schomäcker, M. Kraume, I.M. Mishra, A. Drews, Analyses of polysaccharide fouling mechanisms during crossflow membrane filtration, J. Membr. Sci., 308 (2008) 152-161.

[21] M. Zator, M. Ferrando, F. López, C. Güell, Membrane fouling characterization by confocal microscopy during filtration of BSA/dextran mixtures, J. Membr. Sci., 301 (2007) 57-66.

[22] K. Xiao, X. Wang, X. Huang, T. D. Waite, X. Wen, Analysis of polysaccharide, protein and humic acid retention by microfiltration membranes using Thomas' dynamic adsorption model, J. Membr. Sci., 342 (2009) 22-34.

[23] M.O. Nigam, B. Bansal, X. D. Chen, Fouling and cleaning of whey protein concentrate fouled ultrafiltration membranes, Desalination, 218 (2008) 313-322.

[24] S.A. Mourouzidis-Mourouzis, A.J. Karabelas, Whey protein fouling of microfiltration ceramic membranes-Pressure effects, J. Membr. Sci., 282 (2006) 124-132.

[25] M.D. Carić, S. D. Milanović, D. M. Krstić, M. N. Tekić, Fouling of inorganic membranes by adsorption of whey proteins, J. Membr. Sci., 165 (2000) 83-88.

[26] Y. Hao, A. Moriya, T. Maruyama, Y. Ohmukai, H. Matsuyama, Effect of metal ions on humic acid fouling of hollow fiber ultrafiltration membrane, J. Membr. Sci., 376 (2011) 247-253.

[27] F. Tasselli, A. Cassano, E. Drioli, Ultrafiltration of kiwifruit juice using modified poly(ether ether ketone) hollow fibre membranes, Sep. Purif. Technol., 57 (2007) 94-102.

[28] B. Marcos, C. Moresoli, J. Skorepova, B. Vaughan, CFD modeling of a transient hollow fiber ultrafiltration system for protein concentration, J. Membr. Sci., 337 (2009) 136-144.

[29] T. Chung, J. Qin, J. Gu, Effect of shear rate within the spinneret on morphology, separation performance and mechanical properties of ultrafiltration polyethersulfone hollow fiber membranes, Chem. Eng. Sci., 55 (2000) 1077-1091.

[30] T.Nguyen, S. Yoshikawa, k.Karasu, S.Ookawara, A simple combination model for filtrate flux in crossflow ultrafiltration of protein suspension, J. Membr. Sci, 403-404 (2012) 84-93.

[31] L. Domínguez Chabaliná, M. Rodríguez Pastor, D. Prats Rico, Characterization of soluble and bound EPS obtained from 2 submerged membrane bioreactors by 3D-EEM and HPSEC, Talanta, 115 (2013), 706-712.

[32] C. Viebke, P.A. Williams, Determination of molecular mass distribution of k-carrageenan and xanthan using asymmetrical flow field-flow fractionation, Food hydrocolloids, 14 (2000), 265-270.

[33] S.T. Kelly, A.L. Zydney, Mechanisms for BSA fouling during microfiltration, J. Membr. Sci., 107 (1995), 115-127.

[34] K.J. Hwang, Membrane fouling mechanism and concentration effect in cross-flow microfiltration of BSA/dextran mixtures, Chem. Eng. J., 166 (2011) 669-677. 